\title{
Role of tissue-type plasminogen activator and plasminogen activator inhibitor-1 in psychological stress and depression
}

\author{
Shih-Jen Tsai, ${ }^{1,2}$ \\ ${ }^{1}$ Department of Psychiatry, Taipei Veterans General Hospital, Taipei, Taiwan \\ ${ }^{2}$ School of Medicine, National Yang-Ming University, Taipei, Taiwan \\ Correspondence to: Shih-Jen Tsai, email: tsai610913@gmail.com
}

Keywords: brain-derived neurotrophic factor, tissue-type plasminogen activator, plasminogen activator inhibitor-1, major depressive disorder, stress

Received: May 30, $2017 \quad$ Accepted: July 25, $2017 \quad$ Published: August 04, 2017

Copyright: Tsai. This is an open-access article distributed under the terms of the Creative Commons Attribution License 3.0 (CC BY 3.0), which permits unrestricted use, distribution, and reproduction in any medium, provided the original author and source are credited.

\section{ABSTRACT}

Major depressive disorder is a common illness worldwide, but the pathogenesis of the disorder remains incompletely understood. The tissue-type plasminogen activatorplasminogen proteolytic cascade is highly expressed in the brain regions involved in mood regulation and neuroplasticity. Accumulating evidence from animal and human studies suggests that tissue-type plasminogen activator and its chief inhibitor, plasminogen activator inhibitor-1, are related to stress reaction and depression. Furthermore, the neurotrophic hypothesis of depression postulates that compromised neurotrophin brain-derived neurotrophic factor (BDNF) function is directly involved in the pathophysiology of depression. In the brain, the proteolytic cleavage of proBDNF, a BDNF precursor, to mature BDNF through plasmin represents one mechanism that can change the direction of BDNF action. We also discuss the implications of tissue-type plasminogen activator and plasminogen activator inhibitor-1 alterations as biomarkers for major depressive disorder. Using drugs that increase tissue-type plasminogen activator or decrease plasminogen activator inhibitor-1 levels may open new avenues to develop conceptually novel therapeutic strategies for depression treatment.

\section{INTRODUCTION}

Major depressive disorder (MDD) is a common mental disorder and is one of the leading causes of disability worldwide. Although the exact cause is unknown, several lines of evidences suggest that MDD in most people is caused by a combination of genes and stress, which can change brain chemistry and reduce the ability to maintain mood stability [1]. Genetic factors including genetic variants within genes that operate in stress response mediating neurobiological systems, neurotransmitters, and synaptic plasticity can increase susceptibility for MDD [2].

Synaptic plasticity allows changes in the connectivity between neurons and neuronal circuits permitting adjustment to environmental changes [3]. The mechanisms underlying these neuronal changes in response to either chronic or acute stress have been linked to the pathophysiology of major depression [4]. A group of proteins named neurotrophins are considered powerful molecular mediators in brain synaptic plasticity. Among them, brain-derived neurotrophic factor
(BDNF) has key roles in the neurobiological mechanisms related to major depression [5].

BDNF, a small dimeric protein, is highly expressed in the hippocampus, prefrontal cortex, and amygdala, which are important areas for mood regulation [6]. BDNF can increase synaptic plasticity and its molecular mediators across multiple neurotransmitter systems [7]. Many animal and clinical studies suggest the importance of BDNF in MDD pathogenesis and therapeutic responses. For example, stress, a common precipitating factor for MDD, has been shown to decrease brain BDNF levels. The stress of immobilization can lower BDNF mRNA levels in the rodent hippocampus and other brain regions $[8,9]$. In humans, stress at work reduced serum BDNF levels in hospital employees [10] and traumatic events have been found to be associated with lower BDNF plasma levels in patients with mood disorders [11]. In a clinical study, serum BDNF levels were significantly lower in MDD patients than in controls and depression severity mainly accounted for the negative correlation [12]. In a recent 
study, serum BDNF levels in patients with drug-naïve first-episode MDD were lower than those in the healthy controls [13]. In humans, postmortem studies have shown that brain BDNF was significantly downregulated at the RNA and protein levels in MDD subjects [14]. Some studies have associated a BDNF Val66Met functional polymorphism with MDD susceptibility [15, 16]. The role of BDNF in the pathophysiology of depression is further supported by the observation that the long-term administration of antidepressants in animals upregulates the production of brain BDNF [8]. Furthermore, an infusion of BDNF into the midbrain has an antidepressantlike influence in animal models of depression [17]. In a meta-analyses of eight studies comparing pre- and postantidepressant treatment serum BDNF content, serum BDNF levels were elevated following antidepressant treatment [18].

These findings suggest that BDNF action could be impaired in MDD and that the repair of BDNF deficiency in response to antidepressant treatment may be a major part of the therapeutic mechanisms of antidepressants. However, not all studies support the proposition that decreased BDNF is a major cause of MDD. For example, although BDNFdeficient mice have lower brain BDNF levels than the wild type mice, BDNF-knockout mice did not show depressive behaviors [19]. Furthermore, the baseline BDNF mRNA levels did not differ in two genetic animal models of depression, one bred for helplessness in response to stress and the other bred for resistance to stress [20]. Clinical study by Hung et al. showed that serum BDNF levels presented no significant difference but the serum BDNF receptor (tyrosine kinase receptor $\mathrm{B}$; TrkB) protein levels were significantly higher in MDD patients than in healthy controls [21]. Although treatment with major classes of antidepressants can increase peripheral BDNF levels [22], not all MDD patients benefit from antidepressant treatment, and the symptoms of depression occasionally deteriorate after antidepressant administration [23]. Thus, molecules other than BDNF that activate or inhibit BDNF function may involve in the pathogenesis of MDD.

Tissue-type plasminogen activator (tPA) is a proteolytic enzyme that activates plasminogen to plasmin. tPA is found not only in the blood, where its primary function is as a thrombolytic enzyme, but also in the brain, where it promotes neuronal synaptic plasticity [24]. The aim of this review is to summarize the current knowledge on the role of tPA -plasmin pathway in psychological stress and major depressive disorder. Furthermore, we discuss the development of potential therapeutic agents for major depression through modulating tPA and plasminogen activator inhibitor-1 (PAI-1).

\section{Brain tPA system}

Plasmin is a proteolytic enzyme in the blood that causes fibrinolysis to prevent blood clots from growing.
Plasminogen is the precursor to plasmin and can be converted to plasmin by tPA or the urokinase-type plasminogen activator [25]. Plasminogen activation is further controlled by specific plasminogen activator inhibitors that inhibit the effect of tPA. Among the plasminogen activator inhibitors, PAI-1 is the major endogenous inhibitor for tPA and has been implicated in a variety of thrombotic disorders [26]. The combination of PAI-1 and tPA terminates tPA enzymatic activity in the extracellular space.

The serine protease tPA is produced not only by endothelial cells but also by neurons and microglia of the central nervous system [27]. It is highly expressed in the brain and involves in processes such as learning and memory, stress reaction, neuronal degeneration, and addiction $[27,28]$. In addition to tPA, other tPA-plasmin cascade components such as plasminogen and PAI-1 are also widely present in the brain [27].

\section{Plasmin and BDNF}

BDNF is originally synthesized as the precursor protein proBDNF. In the secretion process, proBDNF can be converted to mature BDNF (mBDNF) by plasmin through the activation of plasminogen, which is dependent on tPA [29] (Figure 1). The functions of BDNF depend on its form (proBDNF or mBDNF) and the activation of two types of receptors. The $\mathrm{p} 75$ neurotrophin receptor (p75NTR) is a low affinity receptor for mBDNF and a high affinity receptor for the proBDNF [30]. The second receptor, neurotrophic tyrosine kinase receptor type 2 (NTRK2), also named TrkB, is a high affinity receptor for mBDNF. ProBDNF binding with high affinity to p75NTR leads to cell apoptosis, whereas mBDNF preferentially activates TrkB to bring about survival [31]. As proBDNF and $\mathrm{mBDNF}$ are assumed to elicit opposing biological effects [31], the regulation on the cleavage of proBDNF to mBDNF by plasmin becomes critical in the pathogenesis and therapeutic effects of major depression [32].

\section{BDNF, proBDNF and depression}

The neurotrophin hypothesis of depression is based chiefly on animal study findings showing that decreased hippocampal BDNF levels are correlated with stressinduced depressive behaviors and that antidepressant administration increases the expression of BDNF [33]. However, increased levels of BDNF were found in some depression studies. For example, communal nest reared mice exhibited increased adulthood levels of BDNF and depressive behavior, which was displayed through higher levels of immobility during the forced swim test [34]. In an earlier study, we also found increased BDNF in the hippocampi of rats in an unpredictable chronic mild stress (UCMS) model of depression compared with control rats [35]. This inconsistency is because limited BDNF antibody 
specificity has prevented most studies that have investigated BDNF levels from distinguishing between proBDNF and mBDNF. In the brain, proBDNF and mBDNF activate two distinct receptors: p75NTR and TrkB. Therefore, methods that can effectively detect proBDNF and mBDNF are critical in discerning the potential depressive and antidepressant effects of BDNF [33].

In a learned helplessness ( $\mathrm{LH}$ ) model of depression, $\mathrm{LH}$ rats showed a reduction of $\mathrm{mBDNF}$ in the medial prefrontal cortex and a decline in CA3 and dentate gyrus of the hippocampus. Furthermore, levels of proBDNF were higher in the medial prefrontal cortex, but lower in the nucleus accumbens, of LH rats [36]. The finding that expression of proBDNF in the medial prefrontal cortex of LH rats was significantly higher than control rats was replicated by the same study group [37]. From these findings, it remains unclear whether these prodepressive effects result from a reduction in $\mathrm{mBDNF}$ levels or an accumulation of proBDNF. Using an UCMS paradigm, Bai et al. have similarly found that stress leads to increased levels of proBDNF, p75NTR, and sortilin but decreased levels of TrkB in the neocortex and hippocampus of rodent brains [38]. Furthermore, chronic administration of fluoxetine abolished this UCMS-induced upregulation of proBDNF. In that study, the injection of anti-proBDNF antibodies via intracerebroventricular and intraperitoneal routes into the UCMS rats significantly improved the stress-induced depressive behaviors and restored exploratory activity and spine growth [38]. Injection of adeno-associated-virus-proBDNF increased the depressive behaviors in naive rats, suggesting that proBDNF may also be implicated in the development of chronic stressinduced depressive behaviors [38]. Recent study also found UCMS caused a decrease in the ratio of BDNF/ proBDNF in the hippocampus and injection of exogenous proBDNF into the CA1 region of rats caused depressivelike behaviors [39]. Another study found that injection of anti-proBDNF in anterior cingulate cortex reverses UCMS-induced depressive behaviors in mice [40].

In 2012, Yoshida et al. first demonstrated that serum levels of mBDNF, but not proBDNF, were significantly lower in patients with MDD than in control subjects [41]. This finding suggested that mBDNF may involve in the pathology of depression or as a biomarker for MDD. However, in another study of 40 drug-free patients with MDD and 50 healthy female controls, the protein and serum levels of proBDNF and p75NTR were higher in patients with MDD than in healthy controls, whereas mBDNF and TrkB levels were lower [42].

With the significant role of proBDNF in depression pathogenesis, tPA or other tPA/plasminogen cascade components such as PAI-1 could be important for depression pathogenesis or therapeutic mechanisms.

\section{Animal studies of tPA and PAI-1 in stress and depression animal models}

Chronic exposure to stressful environments is a key risk factor contributing to the development of depression. Much of the current understanding about the pathogenesis of major depression has come from animal models comprising prolonged physical or social stress. In 2002,

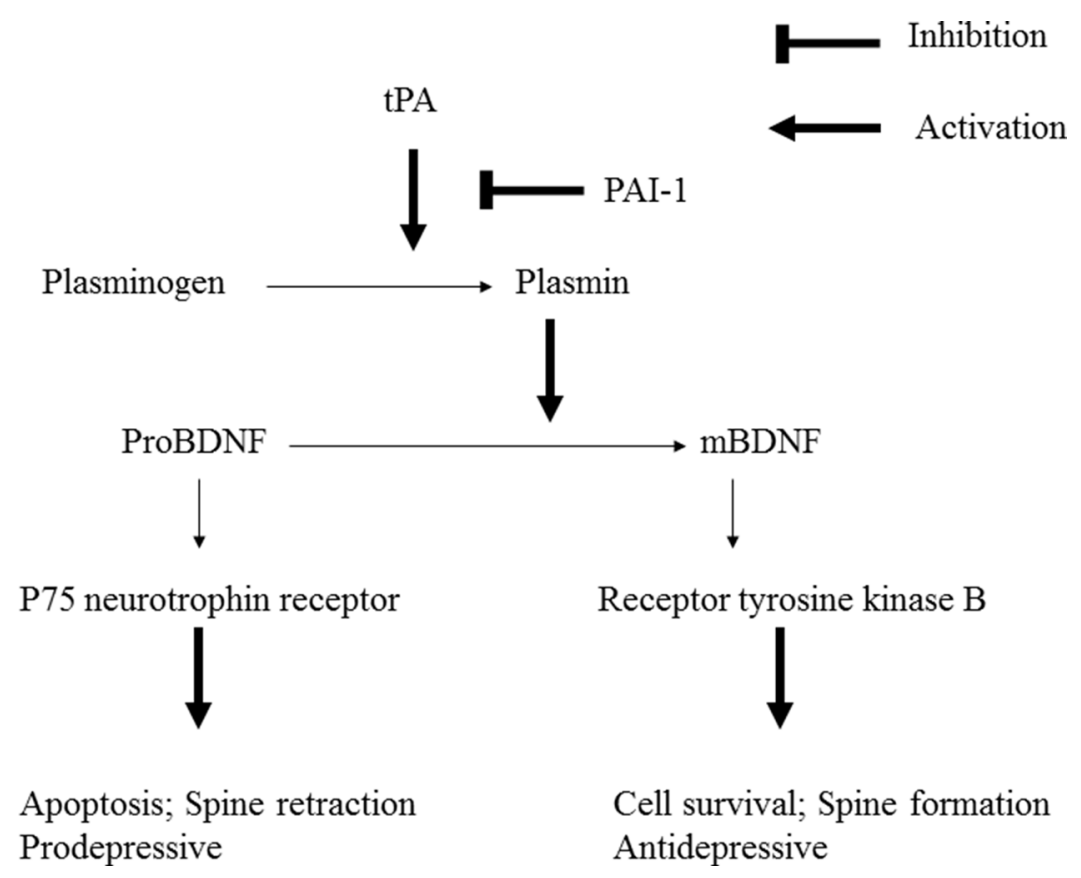

Figure 1: Plasminogen is activated to plasmin by tissue-type plasminogen activator (tPA). Plasminogen activator inhibitor-1 (PAI-1) is the major inhibitor of tPA. Plasmin can cleave the proBDNF to yield mature BDNF (mBDNF). Uncleaved proBDNF binds to the p75 neurotrophin receptor. mBDNF binds to receptor tyrosine kinase B. 
Yamamoto et al. demonstrated that PAI-1 is a major stressregulated gene [43]. In their report, restraint stress led to a dramatic increase of plasma PAI-1 antigen and tissue PAI1 mRNA with maximum induction in a tissue-specific and cell type-specific manner [43]. Similarly, after five weeks of chronic unexpected mild stress (CUMS) procedures, the expressions of PAI- 1 and proBDNF increased in the prefrontal cortex and hippocampus of CUMS rats [44]. Since PAI-1 is the primary inhibitor of tPA, PAI-1 may decrease proBDNF cleavage and increase proBDNF levels by inhibiting the tPA-plasmin system.

Another rodent study suggested that brain tPA is critical for the development of stress-induced behaviors [45]. In that study, tPA was upregulated in the amygdala by acute restraint stress that preceded stress-induced increases of anxiety-like behaviors in mice and was subsequently inhibited by PAI-1. A study that revealed that tPA-knock down in the hippocampus induced depressive behaviors (increased immobility in the forced swim test and tail suspension test) further supported the influential role of tPA in depression [46]. These effects were reversed when tPA-over-expressing vectors were injected in the hippocampus. BDNF protein levels were simultaneously increased in the hippocampi of mice receiving tPAexpressing vectors [46].

\section{Human genetic studies of tPA and PAI-1 in depression}

In humans, PAI-1 is encoded by the SERPINE1 gene. Our genetic association study demonstrated that the genetic variants of SERPINE1 gene may increase MDD susceptibility and the acute therapeutic response to selective serotonin reuptake inhibitors [47]. Another study found that the SERPINE1 gene promoter polymorphisms are involved in the antidepressant treatment of Alzheimer disease-related depression, without association with the depression susceptibility [48].

\section{Clinical studies of tPA and PAI-1 in depression}

Associations between psychological factors, psychological stress, or psychiatric disorders and a state of hypercoagulability have been found in many studies [49].

Many clinical studies have investigated the relationship between the levels of plasma tPA and PAI-1 and psychological stress in MDD patients [50-64] (Table 1). The most consistent finding is elevated plasma PAI-1 levels during psychological stress or depression. The changes of tPA levels during stress reaction and depression are less consistent.

\section{Depression treatment, tPA, and PAI-1}

Studies have tested PAI-1 and tPA levels after depression treatment, medication and non-medication, and their results may further support the role of tPA system in MDD. In an animal study, after five weeks of CUMS to induce a depressive state, PAI-1 and proBDNF had increased in the prefrontal cortex and hippocampus [44]. In that study, the authors further investigated the effects of omega-3 polyunsaturated fatty acids (PUFAs) and sertraline (an antidepressant of the selective serotonin reuptake inhibitor) administration on brain tPA and PAI-1 levels in CUMS rats. Both agents were found to reverse the changes in behavioral tests and induce the expression of tPA in certain brain areas, but they failed to restore the CUMS-induced PAI-1 expression [44]. Moreover, sertraline treatment also accelerated the extracellular conversion of proBDNF into mBDNF in CUMS rats [44]. The later finding is in line with the report that, in human SH-SY5Y cells, treatment with different antidepressants significantly increased the production of mBDNF, but it decreased the production of proBDNF [65]. Similarly, another study found that the long-term administration of highly purified eicosapentaenoic acid, a specific omega-3 fatty acid, significantly and dose-dependently increased the plasma level of tPA and decreased PAI-1 level in rats [66]. A clinical trial in male cigarette smokers also demonstrated that omega-3 fatty acid supplementation increased plasma tPA concentrations [67].

Among human patients with anxiety and depression, Geiser et al., found lower PAI-1 in those given serotonergic antidepressants than in those without [68]. They further demonstrated that patients with anxiety and depression had lower PAI-1 after psychotherapy and improvement of psychiatric symptoms [68]. Recently, Jiang et al. examined serum protein concentrations in the tPA-BDNF pathway obtained from 35 drug-free depressed patients before and after antidepressant treatment and 35 healthy controls [69]. They found serum tPA and BDNF were significantly lower in the depressed patients than in controls, whereas proBDNF was higher. After 8 weeks of antidepressant treatment, $\mathrm{tPA}, \mathrm{BDNF}$ and proBDNF levels were reversed.

Electroconvulsive therapy (ECT) is the most effective treatment for major depression. An animal study by Segawa et al. found that a single administration of electroconvulsive seizures (ECS) rapidly increased hippocampal levels of proBDNF and tPA, whereas rats receiving ten days of repeated ECS, accumulated proBDNF, which resulted in an increase in mBDNF levels [70]. In that study, chronic administration of imipramine (a tricyclic antidepressant) significantly increased mBDNF levels, but not proBDNF and tPA levels, suggesting that the therapeutic mechanism of imipramine differs from that of ECS [70].

Physical exercise has robust antidepressant properties. Mice with access to voluntary physical activity (not locked wheel exposure) for 28 days demonstrated a robust increase in hippocampal mBDNF protein levels and tPA mRNA expression; they also showed antidepressive effects compared with sedentary mice [71]. 


\section{Future research direction}

\section{Plasma tPA and PAI-1 levels as potential MDD peripheral biomarkers}

Diagnostic biomarkers are currently unavailable for MDD diagnosis and treatment, although easily accessible bodily fluids, including blood, are potential sources for the identification of biomarkers. Identification of biomarkers would aid in the diagnosis of MDD and in the selection of effective MDD medications [72]. Clinical studies have mostly showed increased blood PAI-1 levels during depressed or psychologically stressed states (Table 1). PAI-1 levels are affected by gender, age, body mass index, smoking status, and blood pressure. Therefore, these parameters should be introduced as adjusting variables in the analysis of PAI-1 levels in MDD study.

PAI-1 could be important in the cleavage of proBDNF to $\mathrm{mBDNF}$. The ratio of $\mathrm{mBDNF}$ to proBDNF has been reported as a potential differential diagnostic biomarker for MDD and bipolar depression [73]. Previous studies (Table 1) have demonstrated that PAI-1 levels were more related to depressive mood than tPA levels were. Whether blood PAI-1 levels and the mBDNF to proBDNF ratio could be used as clinical biomarkers for MDD diagnosis warrants further exploration.

\section{Dysfunction of the tPA-plasmin pathway: a possible link between MDD and cardiovascular disease}

MDD has been linked to a higher incidence of cardiac events in individuals with cardiovascular disease and in healthy populations [74-76]. Both psychological stress and depression are associated with an activation of coagulation and impairment of fibrinolysis. For example, high resolution two-dimensional Differential Gel Electrophoresis (2D-DIGE) proteome analysis on the platelet proteins found that the levels of fibrinogen beta chain and fibrinogen gamma chain were lower in patients with major depression than in healthy controls [77-79]. While analyzing the plasma proteome collected from MDD patients before the initiation of antidepressant medication, Martins-de-Souza et al. demonstrated high plasma fibrinogen levels are associated with a poor antidepressant response [80].

Hemostatic factors associated with the development of cardiovascular disease include fibrinogen, von Willebrand factor, tPA and PAI-1 [81]. Increased PAI-1 activity is associated with an increased risk of ischemic cardiovascular disease [82]. In addition, evidence from preclinical and clinical studies suggests that $\mathrm{PA}$ and its inhibitor, PAI-1, are related to stress reaction and depression and are important fibrinolytic components. Therefore, dysfunction of the tPA-plasmin pathway could be a link between MDD and cardiovascular disease [83, 84].

\section{Manipulating tPA and PAI-1 levels for MDD treatment}

According to the neurotrophic hypothesis of MDD, restoration of BDNF-TrkB function is the critical action of effective antidepressive treatments, including antidepressants and ECT. Since PAI-1 and tPA may involve in the transformation of proBDNF to $\mathrm{mBDNF}$, tPA over-expression or a decrease in PAI-1 may present therapeutic effects for the treatment of depression especially for patients that have an abnormality in the tPA-plasmin pathway or comorbidities relating to cardiovascular disease. Several studies have reported that medication, ECS, and nutritional supplements may decrease PAI-1 or increase tPA levels.

An animal study demonstrated that omega-3 PUFAs and sertraline administration may induce the expression of tPA and facilitate the transformation of proBDNF to mBDNF in the prefrontal cortex and hippocampus of CUMS rats [44].

Hydroxymethylglutaryl coenzyme A reductase inhibitors, collectively known as statins, are a class of lipid-lowering medications. Some reports have indicated that statin treatment is associated with a reduced risk of depression [85, 86], although the mechanism underlying this antidepressant effect is unknown. In vitro studies have demonstrated that statins (fluvastatin or atorvastatin) inhibit PAI-1 and induce tPA in cultured cells [87, 88]. On the basis of these findings, researchers have postulated that statins may increase the transformation of proBDNF to mBDNF through activation of the tPA-plasmin pathway, thus causing an antidepressive effect [89].

An animal study using UCMS found that depression resulted in an increased expression of PAI-1 and upregulation of the proBDNF to $\mathrm{mBDNF}$ ratio, together with a decreased level of tPA [90]. The proBDNF to mBDNF ratio was further upregulated after ECS treatment in depressive rats [90]. Propofol alone did not reverse the changes in depressive rats, but when coadministered with ECS, it downregulated the proBDNF to mBDNF ratio, and increased tPA expression. The results of this study suggest that propofol combined with ECT may decrease the proBDNF to mBDNF ratio by increasing tPA expression [90].

Researchers studied a two-week fiber supplement in eleven healthy volunteer subjects who were instructed to consume oat husk tablets in addition to their regular diets [91]. Compared to the baseline, oat husk supplementation resulted in a reduction of plasma PAI-1 activity, and a six week washout period returned the PAI-1 activity level to the baseline. Thus, whether oat husk supplement has an antidepressive effect warrants further exploration.

\section{Other mental disorders, tPA, and PAI-1}

Previous studies have found altered tPA and PAI1 levels in psychological stress and MDD. Changes in tPA 
Table 1: Studies of peripheral tissue-type plasminogen activator (tPA) and plasminogen activator inhibitor-1 (PAI-1) levels to psychological stress and in MDD

\begin{tabular}{|c|c|c|c|}
\hline $\begin{array}{c}\text { Authors and Year } \\
\text { of Publication }\end{array}$ & Study design and Subjects & Significant Findings & Adjusting confounders \\
\hline Jern et al. (1994) & $\begin{array}{l}\text { Mental stress (forced arithmetic) } \\
\text { in } 11 \text { healthy young males }\end{array}$ & $\begin{array}{l}\text { Plasma tPA levels increased } \\
\text { significantly during stress. }\end{array}$ & None \\
\hline $\begin{array}{l}\text { Räikkönen et al. } \\
\text { (1996) }\end{array}$ & $\begin{array}{l}\text { Chronic stress in } 69 \text { healthy } \\
\text { middle-aged men }\end{array}$ & Increased plasma PAI-1 levels. & $\begin{array}{l}\text { age, smoking, alcohol } \\
\text { consumption, physical activity, } \\
\text { and metabolic factors }\end{array}$ \\
\hline $\begin{array}{l}\text { Ishizaki et al. } \\
\text { (1996) }\end{array}$ & $\begin{array}{l}\text { Psychosocial job stress in } 213 \\
\text { middle aged male workers }\end{array}$ & $\begin{array}{l}\text { High job demands were significantly } \\
\text { related to decreases in tPA activity. }\end{array}$ & $\begin{array}{l}\text { age, BMI, blood pressure, } \\
\text { serum lipids, and smoking }\end{array}$ \\
\hline $\begin{array}{l}\text { Vrijkotte et al. } \\
\text { (1999) }\end{array}$ & $\begin{array}{l}\text { Work stress in } 124 \text { middle-aged, } \\
\text { white-collar workers }\end{array}$ & $\begin{array}{l}\text { Decreased tPA and increased PAI-1 } \\
\text { plasma levels. }\end{array}$ & $\begin{array}{l}\text { age, BMI, smoking habits, } \\
\text { alcohol consumption, and } \\
\text { physical activity }\end{array}$ \\
\hline Hevey et al. (2000) & 11 cardiac patients & $\begin{array}{l}\text { Acute psychological stress decreased } \\
\text { tPA and tPA/PAI-1 complexes. }\end{array}$ & None \\
\hline $\begin{array}{l}\text { von Känel et al. } \\
\text { (2004) }\end{array}$ & $\begin{array}{l}48 \text { community-dwelling elderly } \\
\text { subjects }\end{array}$ & $\begin{array}{l}\text { Mental stress elicited a decrease in } \\
\text { tPA. }\end{array}$ & $\begin{array}{l}\text { age, gender, BMI, blood } \\
\text { pressure, serum lipids, and } \\
\text { smoking }\end{array}$ \\
\hline $\begin{array}{l}\text { Eskandari et al. } \\
(2005)\end{array}$ & $\begin{array}{l}45 \text { premenopausal women with } \\
\text { MDD vs } 28 \text { healthy controls }\end{array}$ & $\begin{array}{l}\text { The MDD group exhibited } \\
\text { statistically higher blood PAI-1 } \\
\text { levels. }\end{array}$ & age, gender, BMI, and smoking \\
\hline $\begin{array}{l}\text { Lahlou-Laforet } \\
\text { et al. (2006) }\end{array}$ & $\begin{array}{l}231 \text { men ( } 40 \text { to } 65 \text { years old; } \\
123 \text { without coronary heart } \\
\text { disease and } 108 \text { with coronary } \\
\text { heart disease) }\end{array}$ & $\begin{array}{l}\text { Plasma PAI-1 levels were higher in } \\
\text { depressed subjects. }\end{array}$ & $\begin{array}{l}\text { age, gender, BMI, blood } \\
\text { pressure, serum lipids, and } \\
\text { smoking }\end{array}$ \\
\hline $\begin{array}{l}\text { Matthews et al. } \\
\text { (2007) }\end{array}$ & 3292 community women & $\begin{array}{l}\text { Higher depressive symptoms were } \\
\text { related to higher plasma PAI-1 and } \\
\text { tPA levels. }\end{array}$ & $\begin{array}{l}\text { age, gender, BMI, blood } \\
\text { pressure, physical activity, and } \\
\text { menopausal status }\end{array}$ \\
\hline $\begin{array}{l}\text { Mausbach et al. } \\
(2008)\end{array}$ & 71 spousal dementia caregivers & $\begin{array}{l}\text { Negative life events were positively } \\
\text { associated with plasma PAI-1 } \\
\text { concentrations in participants low } \\
\text { in personal mastery but not in } \\
\text { individuals high in personal mastery. }\end{array}$ & $\begin{array}{l}\text { BMI, blood pressure, and } \\
\text { metabolic factors }\end{array}$ \\
\hline Geiser et al. (2008) & $\begin{array}{l}\text { Anxiety patients (panic disorder } \\
\text { with agoraphobia or social } \\
\text { phobia) and control group (each } \\
\mathrm{n}=29 \text { ) }\end{array}$ & $\begin{array}{l}\text { Higher levels of PAI-1 in the patient } \\
\text { group. }\end{array}$ & $\begin{array}{l}\text { age, gender, BMI, blood } \\
\text { pressure, smoking, alcohol } \\
\text { consumption, physical activity, } \\
\text { and metabolic factors }\end{array}$ \\
\hline Pan et al. (2008) & $\begin{array}{l}3289 \text { community residents aged } \\
50-70\end{array}$ & $\begin{array}{l}\text { Depressive symptoms were not } \\
\text { associated with plasma PAI-1 levels. }\end{array}$ & $\begin{array}{l}\text { age, gender, BMI, blood } \\
\text { pressure, smoking, alcohol } \\
\text { consumption, physical activity, } \\
\text { and metabolic factors }\end{array}$ \\
\hline Shi et al. (2010) & $\begin{array}{l}24 \text { late-onset geriatric MDD and } \\
30 \text { control subjects }\end{array}$ & $\begin{array}{l}\text { Baseline plasma BDNF and tPA } \\
\text { levels were significantly lower in } \\
\text { MDD patients. }\end{array}$ & age, gender, and BMI \\
\hline Smith et al. (2014) & $\begin{array}{l}18 \text { male firefighters performed } \\
18 \text { min of simulated firefighting } \\
\text { activities }\end{array}$ & $\begin{array}{l}\text { tPA was enhanced immediately post } \\
\text { firefighting but returned to baseline } \\
\text { values by } 2 \text { h post firefighting. PAI- } 1 \\
\text { was depressed at } 2 \text { h post firefighting. }\end{array}$ & None \\
\hline Malan et al. (2016) & $\begin{array}{l}181 \text { black African urban- } \\
\text { dwelling teachers ( } 88 \text { men, } 93 \\
\text { women; aged } 25-60 \text { years })\end{array}$ & $\begin{array}{l}\text { In black men only, } \\
\text { depressive symptoms were positively } \\
\text { associated with plasma PAI- } 1 \text { levels. }\end{array}$ & $\begin{array}{l}\text { age, BMI, physical activity, } \\
\text { blood pressure, and serum } \\
\text { lipids }\end{array}$ \\
\hline
\end{tabular}

BMI: body mass index 
and PAI-1 levels have also been reported in schizophrenia [92, 93], addiction [94], and in disorders characterized by learning and memory deficits and by neuronal deterioration, such as Alzheimer disease [95]. Therefore, the dysfunction of the tPAplasmin system might represent a common pathophysiological mechanism shared by several mental diseases.

\section{Limitations}

Current major limitation in our understanding of the tPA-plasmin system and BDNF in depression is the lack of larger clinical depression studies that investigate the association between PA, PAI-1, plasmin, proBDNF and $\mathrm{mBDNF}$. In addition, the function of the tPA-plasmin system is largely determined by genetic factors [96]. Genetic studies (e.g., mutation analysis, microarray, or genetic association studies) of genes related to the tPAplasmin system in MDD are rare and the small sample sizes of these studies may limit statistical power.

\section{CONCLUSIONS}

Synaptic plasticity and proBDNF cleavage, which are mediated by tPA, are crucial processes for mood regulation. Because the etiology of MDD is heterogeneous, the hypothesis that tPA-PAI-1 dysfunction might explain some MDD pathophysiology is supported by the animal studies, plasma level changes in humans under stress or depression, human genetic studies, and antidepressive treatment. The enhancement of PAI-1 levels seems to be a common finding under stressed or depressed states, and it may be a candidate for a biological marker for depression. Additional studies are needed to determine how interventions aiming specifically at correcting activity of tPA or PAI-1 may contribute to novel strategies for the management of this common mental disorder.

\section{ACKNOWLEDGMENTS AND FUNDING}

This work was supported by grant MOST 104-2314B-075 -072 -MY3 and MOST 104-2745-B-075-002 from Taiwan Ministry of Science and Technology, and grants V105E17-002-MY2-1, V105C-008, VGHUST103-G1-4-1 from the Taipei Veterans General Hospital. We acknowledge Wallace Academic Editing for editing this manuscript.

\section{CONFLICTS OF INTEREST}

The author has no other potential conflict of interest to disclose.

\section{REFERENCES}

1. Lopizzo N, Bocchio Chiavetto L, Cattane N, Plazzotta G, Tarazi FI, Pariante CM, Riva MA, Cattaneo A. Geneenvironment interaction in major depression: focus on experience-dependent biological systems. Front Psychiatry. 2015; 6:68. https://doi.org/10.3389/fpsyt.2015.00068.

2. Roy M, Tapadia MG, Joshi S, Koch B. Molecular and genetic basis of depression. J Genet. 2014; 93:879-92.

3. Marsden WN. Synaptic plasticity in depression: molecular, cellular and functional correlates. Prog Neuropsychopharmacol Biol Psychiatry. 2013; 43:168-84. https://doi.org/10.1016/j.pnpbp.2012.12.012.

4. Duman RS, Aghajanian GK, Sanacora G, Krystal JH. Synaptic plasticity and depression: new insights from stress and rapid-acting antidepressants. Nat Med. 2016; 22:238-49. https://doi.org/10.1038/nm.4050.

5. Duman RS, Heninger GR, Nestler EJ. A molecular and cellular theory of depression. Arch Gen Psychiatry. 1997; 54:597-606.

6. Hofer M, Pagliusi SR, Hohn A, Leibrock J, Barde YA. Regional distribution of brain-derived neurotrophic factor mRNA in the adult mouse brain. EMBO J. 1990; 9:2459-64.

7. McAllister AK, Katz LC, Lo DC. Neurotrophins and synaptic plasticity. Annu Rev Neurosci. 1999; 22:295-318. https://doi.org/10.1146/annurev.neuro.22.1.295.

8. Nibuya M, Morinobu S, Duman RS. Regulation of BDNF and trkB mRNA in rat brain by chronic electroconvulsive seizure and antidepressant drug treatments. J Neurosci. $1995 ; 15: 7539-47$.

9. Ueyama T, Kawai Y, Nemoto K, Sekimoto M, Tone S, Senba E. Immobilization stress reduced the expression of neurotrophins and their receptors in the rat brain. Neurosci Res. 1997; 28:103-10.

10. Mitoma M, Yoshimura R, Sugita A, Umene W, Hori H, Nakano H, Ueda N, Nakamura J. Stress at work alters serum brain-derived neurotrophic factor (BDNF) levels and plasma 3-methoxy-4-hydroxyphenylglycol (MHPG) levels in healthy volunteers: BDNF and MHPG as possible biological markers of mental stress? Prog Neuropsychopharmacol Biol Psychiatry. 2008; 32:679-85. https://doi.org/10.1016/j.pnpbp.2007.11.011.

11. Dell'Osso L, Carmassi C, Del Debbio A, Catena Dell'Osso M, Bianchi C, da Pozzo E, Origlia N, Domenici L, Massimetti G, Marazziti D, Piccinni A. Brain-derived neurotrophic factor plasma levels in patients suffering from post-traumatic stress disorder. Prog Neuropsychopharmacol Biol Psychiatry. 2009; 33:899-902. https://doi.org/10.1016/j.pnpbp.2009.04.018.

12. Karege F, Perret G, Bondolfi G, Schwald M, Bertschy G, Aubry JM. Decreased serum brain-derived neurotrophic factor levels in major depressed patients. Psychiatry Res. 2002; 109:143-8.

13. Chiou YJ, Huang TL. Serum Brain-Derived Neurotrophic Factors in Taiwanese Patients with Drug-Naive FirstEpisode Major Depressive Disorder: Effects of Antidepressants. Int J Neuropsychopharmacol. 2017; 20:213-8. https://doi.org/10.1093/ijnp/pyw096.

14. Guilloux JP, Douillard-Guilloux G, Kota R, Wang X, Gardier AM, Martinowich K, Tseng GC, Lewis DA, 
Sibille E. Molecular evidence for BDNF- and GABArelated dysfunctions in the amygdala of female subjects with major depression. Mol Psychiatry. 2012; 17:1130-42. https://doi.org/10.1038/mp.2011.113.

15. Hwang JP, Tsai SJ, Hong CJ, Yang CH, Lirng JF, Yang YM. The Val66Met polymorphism of the brain-derived neurotrophic-factor gene is associated with geriatric depression. Neurobiol Aging. 2006; 27:1834-7. https://doi. org/10.1016/j.neurobiolaging.2005.10.013.

16. Taylor WD, Zuchner S, McQuoid DR, Steffens DC, Speer MC, Krishnan KR. Allelic differences in the brainderived neurotrophic factor Val66Met polymorphism in latelife depression. Am J Geriatr Psychiatry. 2007; 15:850-7. https://doi.org/10.1097/JGP.0b013e318050c9d5.

17. Siuciak JA, Lewis DR, Wiegand SJ, Lindsay RM. Antidepressant-like effect of brain-derived neurotrophic factor (BDNF). Pharmacol Biochem Behav. 1997; 56:131-7. https://doi.org/10.1016/S0091-3057(96)00169-4.

18. Sen S, Duman R, Sanacora G. Serum brain-derived neurotrophic factor, depression, and antidepressant medications: meta-analyses and implications. Biol Psychiatry. 2008; 64:527-32. https://doi.org/10.1016/j. biopsych.2008.05.005.

19. MacQueen GM, Ramakrishnan K, Croll SD, Siuciak JA, Yu G, Young LT, Fahnestock M. Performance of heterozygous brain-derived neurotrophic factor knockout mice on behavioral analogues of anxiety, nociception, and depression. Behav Neurosci. 2001; 115:1145-53.

20. Vollmayr B, Faust H, Lewicka S, Henn FA. Brain-derivedneurotrophic-factor (BDNF) stress response in rats bred for learned helplessness. Mol Psychiatry. 2001; 6:471-4, 358. https://doi.org/10.1038/sj.mp.4000907.

21. Hung YY, Lin CJ, Huang TL. Higher serum tropomyosinrelated kinase B protein level in major depression. Prog Neuropsychopharmacol Biol Psychiatry. 2010; 34:610-2. https://doi.org/10.1016/j.pnpbp.2010.02.021.

22. Polyakova M, Stuke K, Schuemberg K, Mueller K, Schoenknecht P, Schroeter ML. BDNF as a biomarker for successful treatment of mood disorders: a systematic \& quantitative meta-analysis. J Affect Disord. 2015; 174:432-40. https://doi.org/10.1016/j.jad.2014.11.044.

23. Tsai SJ. Possible involvement of the BDNF-dependent pathway in treatment-emergent suicidality or decreased response to antidepressants. Med Hypotheses. 2005; 65:942-6. https://doi.org/10.1016/j.mehy.2005.05.010.

24. Lee TW, Tsang VW, Birch NP. Physiological and pathological roles of tissue plasminogen activator and its inhibitor neuroserpin in the nervous system. Front Cell Neurosci. 2015; 9:396. https://doi.org/10.3389/ fncel.2015.00396.

25. Collen D. Ham-Wasserman lecture: role of the plasminogen system in fibrin-homeostasis and tissue remodeling. Hematology Am Soc Hematol Educ Program. 2001:1-9.

26. van Mourik JA, Lawrence DA, Loskutoff DJ. Purification of an inhibitor of plasminogen activator (antiactivator) synthesized by endothelial cells. J Biol Chem. 1984; 259:14914-21.

27. Melchor JP, Strickland S. Tissue plasminogen activator in central nervous system physiology and pathology. Thromb Haemost. 2005; 93:655-60. https://doi.org/10.1160/TH0412-0838.

28. Melchor JP, Pawlak R, Strickland S. The tissue plasminogen activator-plasminogen proteolytic cascade accelerates amyloid-beta (Abeta) degradation and inhibits Abetainduced neurodegeneration. J Neurosci. 2003; 23:8867-71.

29. Pang PT, Teng HK, Zaitsev E, Woo NT, Sakata K, Zhen S, Teng KK, Yung WH, Hempstead BL, Lu B. Cleavage of proBDNF by tPA/plasmin is essential for long-term hippocampal plasticity. Science. 2004; 306:487-91. https:// doi.org/10.1126/science.1100135.

30. Rodriguez-Tebar A, Dechant G, Barde YA. Binding of brain-derived neurotrophic factor to the nerve growth factor receptor. Neuron. 1990; 4:487-92.

31. Lu B, Pang PT, Woo NH. The yin and yang of neurotrophin action. Nat Rev Neurosci. 2005; 6:603-14. https://doi. org/10.1038/nrn1726.

32. Tsai SJ. The possible role of tissue-type plasminogen activator and the plasminogen system in the pathogenesis of major depression. Med Hypotheses. 2006; 66:319-22. https://doi.org/10.1016/j.mehy.2005.10.009.

33. Martinowich K, Manji H, Lu B. New insights into BDNF function in depression and anxiety. Nat Neurosci. 2007; 10:1089-93. https://doi.org/10.1038/nn1971.

34. Branchi I, D'Andrea I, Sietzema J, Fiore M, Di Fausto V, Aloe L, Alleva E. Early social enrichment augments adult hippocampal BDNF levels and survival of BrdU-positive cells while increasing anxiety- and "depression"-like behavior. J Neurosci Res. 2006; 83:965-73. https://doi. org/10.1002/jnr.20789.

35. Luo KR, Hong CJ, Liou YJ, Hou SJ, Huang YH, Tsai SJ. Differential regulation of neurotrophin S100B and BDNF in two rat models of depression. Prog Neuropsychopharmacol Biol Psychiatry. 2010; 34:1433-9. https://doi.org/10.1016/j. pnpbp.2010.07.033.

36. Shirayama Y, Yang C, Zhang JC, Ren Q, Yao W, Hashimoto K. Alterations in brain-derived neurotrophic factor (BDNF) and its precursor proBDNF in the brain regions of a learned helplessness rat model and the antidepressant effects of a TrkB agonist and antagonist. Eur Neuropsychopharmacol. 2015; 25:2449-58. https://doi.org/10.1016/j.euroneuro.2015.09.002.

37. Yang B, Yang C, Ren Q, Zhang JC, Chen QX, Shirayama Y, Hashimoto K. Regional differences in the expression of brain-derived neurotrophic factor (BDNF) pro-peptide, proBDNF and preproBDNF in the brain confer stress resilience. Eur Arch Psychiatry Clin Neurosci. 2016; 266: 765-9. https://doi.org/10.1007/s00406-016-0693-6.

38. Bai YY, Ruan CS, Yang CR, Li JY, Kang ZL, Zhou L, Liu D, Zeng YQ, Wang TH, Tian CF, Liao H, Bobrovskaya L, Zhou XF. ProBDNF Signaling Regulates DepressionLike Behaviors in Rodents under Chronic Stress. 
Neuropsychopharmacology. 2016; 41:2882-92. https://doi. org/10.1038/npp.2016.100.

39. Qiao H, An SC, Xu C, Ma XM. Role of proBDNF and $\mathrm{BDNF}$ in dendritic spine plasticity and depressive-like behaviors induced by an animal model of depression. Brain Res. 2017; 1663:29-37. https://doi.org/10.1016/j. brainres.2017.02.020.

40. Yang CR, Bai YY, Ruan CS, Zhou FH, Li F, Li CQ, Zhou XF. Injection of Anti-proBDNF in Anterior Cingulate Cortex (ACC) Reverses Chronic Stress-Induced Adverse Mood Behaviors in Mice. Neurotox Res. 2017; 31:298-308. https://doi.org/10.1007/s12640-016-9687-4.

41. Yoshida T, Ishikawa M, Niitsu T, Nakazato M, Watanabe $H$, Shiraishi T, Shiina A, Hashimoto T, Kanahara N, Hasegawa T, Enohara M, Kimura A, Iyo M, et al. Decreased serum levels of mature brain-derived neurotrophic factor (BDNF), but not its precursor proBDNF, in patients with major depressive disorder. PLoS One. 2012; 7:e42676. https://doi.org/10.1371/journal.pone.0042676.

42. Zhou L, Xiong J, Lim Y, Ruan Y, Huang C, Zhu Y, Zhong JH, Xiao Z, Zhou XF. Upregulation of blood proBDNF and its receptors in major depression. J Affect Disord. 2013; 150:776-84. https://doi.org/10.1016/j.jad.2013.03.002.

43. Yamamoto K, Takeshita K, Shimokawa T, Yi H, Isobe K, Loskutoff DJ, Saito H. Plasminogen activator inhibitor-1 is a major stress-regulated gene: implications for stressinduced thrombosis in aged individuals. Proc Natl Acad Sci USA. 2002; 99:890-5. https://doi.org/10.1073/ pnas.022608799.

44. Tang M, Jiang P, Li H, Cai H, Liu Y, Gong H, Zhang L. Antidepressant-like effect of n-3 PUFAs in CUMS rats: role of tPA/PAI-1 system. Physiol Behav. 2015; 139:210-5. https://doi.org/10.1016/j.physbeh.2014.11.054.

45. Pawlak R, Magarinos AM, Melchor J, McEwen B, Strickland S. Tissue plasminogen activator in the amygdala is critical for stress-induced anxiety-like behavior. Nat Neurosci. 2003; 6:168-74. https://doi.org/10.1038/nn998.

46. Bahi A, Dreyer JL. Hippocampus-specific deletion of tissue plasminogen activator "tPA" in adult mice impairs depression- and anxiety-like behaviors. Eur Neuropsychopharmacol. 2012; 22:672-82. https://doi. org/10.1016/j.euroneuro.2012.01.008.

47. Tsai SJ, Hong CJ, Liou YJ, Yu YW, Chen TJ. Plasminogen activator inhibitor-1 gene is associated with major depression and antidepressant treatment response. Pharmacogenet Genomics. 2008; 18:869-75. https:/doi. org/10.1097/FPC.0b013e328308bbc0.

48. Fang Y, Zhang L, Zeng Z, Lian Y, Jia Y, Zhu H, Xu Y. Promoter polymorphisms of SERPINE1 are associated with the antidepressant response to depression in Alzheimer's disease. Neurosci Lett. 2012; 516:217-20. https://doi. org/10.1016/j.neulet.2012.03.090.

49. von Kanel R, Mills PJ, Fainman C, Dimsdale JE. Effects of psychological stress and psychiatric disorders on blood coagulation and fibrinolysis: a biobehavioral pathway to coronary artery disease? Psychosom Med. 2001; 63:531-44.

50. Malan L, Mashele N, Malan NT, Harvey BH, Potgieter JC, Van Rooyen JM. Depression Symptoms Facilitated Fibrinolytic Dysregulation and Future Coronary Artery Disease Risk in a Black Male Cohort: The Sympathetic Activity and Ambulatory Blood Pressure in Africans Study. J Cardiovasc Nurs. 2016. https://doi.org/10.1097/ JCN.0000000000000358.

51. Mausbach BT, von Kanel R, Patterson TL, Dimsdale JE, Depp CA, Aschbacher K, Mills PJ, Ancoli-Israel S, Grant I. The moderating effect of personal mastery and the relations between stress and Plasminogen Activator Inhibitor-1 (PAI1) antigen. Health Psychol. 2008; 27:S172-9. https://doi. org/10.1037/0278-6133.27.2(Suppl.).S172.

52. Eskandari F, Mistry S, Martinez PE, Torvik S, Kotila C, Sebring N, Drinkard BE, Levy C, Reynolds JC, Csako G, Gold PW, Horne M, Cizza G, et al. Younger, premenopausal women with major depressive disorder have more abdominal fat and increased serum levels of prothrombotic factors: implications for greater cardiovascular risk. Metabolism. 2005; 54:918-24. https://doi.org/10.1016/j. metabol.2005.02.006.

53. Lahlou-Laforet K, Alhenc-Gelas M, Pornin M, Bydlowski S, Seigneur E, Benetos A, Kierzin JM, Scarabin PY, Ducimetiere P, Aiach M, Guize L, Consoli SM. Relation of depressive mood to plasminogen activator inhibitor, tissue plasminogen activator, and fibrinogen levels in patients with versus without coronary heart disease. Am J Cardiol. 2006; 97:1287-91. https://doi.org/10.1016/j.amjcard.2005.11.062.

54. Geiser F, Meier C, Wegener I, Imbierowicz K, Conrad R, Liedtke R, Oldenburg J, Harbrecht U. Association between anxiety and factors of coagulation and fibrinolysis. Psychother Psychosom. 2008; 77:377-83. https://doi. org/10.1159/000151518.

55. Matthews KA, Schott LL, Bromberger J, Cyranowski J, Everson-Rose SA, Sowers MF. Associations between depressive symptoms and inflammatory/hemostatic markers in women during the menopausal transition. Psychosom Med. 2007; 69:124-30. https://doi.org/10.1097/01. psy.0000256574.30389.1b.

56. Smith DL, Horn GP, Petruzzello SJ, Fahey G, Woods J, Fernhall B. Clotting and fibrinolytic changes after firefighting activities. Med Sci Sports Exerc. 2014; 46:448-54. https:// doi.org/10.1249/MSS.0b013e3182a76dd2.

57. Shi Y, You J, Yuan Y, Zhang X, Li H, Hou G. Plasma BDNF and tPA are associated with late-onset geriatric depression. Psychiatry Clin Neurosci. 2010; 64:249-54. https://doi. org/10.1111/j.1440-1819.2010.02074.x.

58. Hevey D, McGee HM, Fitzgerald D, Horgan JH. Acute psychological stress decreases plasma tissue plasminogen activator (tPA) and tissue plasminogen activator/ plasminogen activator inhibitor-1 (tPA/PAI-1) complexes in cardiac patients. Eur J Appl Physiol. 2000; 83:344-8. https://doi.org/10.1007/s004210000299. 
59. von Kanel R, Dimsdale JE, Adler KA, Patterson TL, Mills PJ, Grant I. Effects of depressive symptoms and anxiety on hemostatic responses to acute mental stress and recovery in the elderly. Psychiatry Res. 2004; 126:253-64. https://doi.org/10.1016/j.psychres.2004.02.003.

60. Vrijkotte TG, van Doornen LJ, de Geus EJ. Work stress and metabolic and hemostatic risk factors. Psychosom Med. 1999; 61:796-805.

61. Raikkonen K, Lassila R, Keltikangas-Jarvinen L, Hautanen A. Association of chronic stress with plasminogen activator inhibitor-1 in healthy middle-aged men. Arterioscler Thromb Vasc Biol. 1996; 16:363-7.

62. Ishizaki M, Tsuritani I, Noborisaka Y, Yamada Y, Tabata M, Nakagawa H. Relationship between job stress and plasma fibrinolytic activity in male Japanese workers. Int Arch Occup Environ Health. 1996; 68:315-20.

63. Jern C, Selin L, Jern S. In vivo release of tissue-type plasminogen activator across the human forearm during mental stress. Thromb Haemost. 1994; 72:285-91.

64. Pan A, Ye X, Franco OH, Li H, Yu Z, Wang J, Qi Q, Gu W, Pang X, Liu H, Lin X. The association of depressive symptoms with inflammatory factors and adipokines in middle-aged and older Chinese. PLoS One. 2008; 3: e1392. https://doi.org/10.1371/journal.pone.0001392.

65. Lin PY. Regulation of proteolytic cleavage of brain-derived neurotrophic factor precursor by antidepressants in human neuroblastoma cells. Neuropsychiatr Dis Treat. 2015; 11:2529-32. https://doi.org/10.2147/NDT.S87743.

66. Nobukata H, Ishikawa T, Obata M, Shibutani Y. Long-term administration of highly purified eicosapentaenoic acid ethyl ester prevents diabetes and abnormalities of blood coagulation in male WBN/Kob rats. Metabolism. 2000; 49:912-9. https://doi.org/10.1053/meta.2000.6739.

67. Din JN, Sarma J, Harding SA, Lyall K, Newby DE, Flapan AD. Effect of omega-3 fatty acid supplementation on endothelial function, endogenous fibrinolysis and platelet activation in patients with a previous myocardial infarction: a randomised controlled trial. BMJ Open. 2013; 3:e003054. https://doi.org/10.1136/bmjopen-2013-003054.

68. Geiser F, Conrad R, Imbierowicz K, Meier C, Liedtke R, Klingmuller D, Oldenburg J, Harbrecht U. Coagulation activation and fibrinolysis impairment are reduced in patients with anxiety and depression when medicated with serotonergic antidepressants. Psychiatry Clin Neurosci. 2011; 65:518-25. https://doi.org/10.1111/j.14401819.2011.02241.x.

69. Jiang H, Chen S, Li C, Lu N, Yue Y, Yin Y, Zhang Y, Zhi X, Zhang D, Yuan Y. The serum protein levels of the tPA-BDNF pathway are implicated in depression and antidepressant treatment. Transl Psychiatry. 2017; 7:e1079. https://doi.org/10.1038/tp.2017.43.

70. Segawa M, Morinobu S, Matsumoto T, Fuchikami M, Yamawaki S. Electroconvulsive seizure, but not imipramine, rapidly up-regulates pro-BDNF and t-PA, leading to mature BDNF production, in the rat hippocampus. Int $\mathrm{J}$
Neuropsychopharmacol. 2013; 16:339-50. https://doi. org/10.1017/S1461145712000053.

71. Sartori CR, Vieira AS, Ferrari EM, Langone F, Tongiorgi E, Parada CA. The antidepressive effect of the physical exercise correlates with increased levels of mature BDNF, and proBDNF proteolytic cleavage-related genes, p11 and tPA. Neuroscience. 2011; 180:9-18. https://doi. org/10.1016/j.neuroscience.2011.02.055.

72. Huang TL, Lin CC. Advances in biomarkers of major depressive disorder. Adv Clin Chem. 2015; 68:177-204. https://doi.org/10.1016/bs.acc.2014.11.003.

73. Zhao G, Zhang C, Chen J, Su Y, Zhou R, Wang F, Xia W, Huang J, Wang Z, Hu Y, Cao L, Guo X, Yuan C, et al. Ratio of $\mathrm{mBDNF}$ to proBDNF for Differential Diagnosis of Major Depressive Disorder and Bipolar Depression. Mol Neurobiol. 2016. https://doi.org/10.1007/s12035-016-0098-6.

74. Lichtman JH, Froelicher ES, Blumenthal JA, Carney RM, Doering LV, Frasure-Smith N, Freedland KE, Jaffe AS, Leifheit-Limson EC, Sheps DS, Vaccarino V, Wulsin L, American Heart Association Statistics Committee of the Council on E, et al. Depression as a risk factor for poor prognosis among patients with acute coronary syndrome: systematic review and recommendations: a scientific statement from the American Heart Association. Circulation. 2014; 129:1350-69. https://doi.org/10.1161/ CIR.0000000000000019.

75. Wulsin LR, Singal BM. Do depressive symptoms increase the risk for the onset of coronary disease? A systematic quantitative review. Psychosom Med. 2003; 65:201-10.

76. Cohen BE, Edmondson D, Kronish IM. State of the Art Review: Depression, Stress, Anxiety, and Cardiovascular Disease. Am J Hypertens. 2015; 28:1295-302. https://doi. org/10.1093/ajh/hpv047.

77. Huang TL, Sung ML, Chen TY. 2D-DIGE proteome analysis on the platelet proteins of patients with major depression. Proteome Sci. 2014; 12:1. https://doi. org/10.1186/1477-5956-12-1.

78. Huang TL, Cho YT, Su H, Shiea J. Principle component analysis combined with matrix-assisted laser desorption ionization mass spectrometry for rapid diagnosing the sera of patients with major depression. Clin Chim Acta. 2013; 424:175-81. https://doi.org/10.1016/j.cca.2013.06.003.

79. Lo LH, Huang TL, Shiea J. Acid hydrolysis followed by matrix-assisted laser desorption/ionization mass spectrometry for the rapid diagnosis of serum protein biomarkers in patients with major depression. Rapid Commun Mass Spectrom. 2009; 23:589-98. https://doi. org/10.1002/rcm.3908.

80. Martins-de-Souza D, Maccarrone G, Ising M, Kloiber S, Lucae S, Holsboer F, Turck CW. Plasma fibrinogen: now also an antidepressant response marker? Transl Psychiatry. 2014; 4:e352. https://doi.org/10.1038/tp.2013.129.

81. Kannel WB. Overview of hemostatic factors involved in atherosclerotic cardiovascular disease. Lipids. 2005; 40:1215-20. 
82. Ha H, Oh EY, Lee HB. The role of plasminogen activator inhibitor 1 in renal and cardiovascular diseases. Nat Rev Nephrol. 2009; 5:203-11. https://doi.org/10.1038/ nrneph.2009.15.

83. Hou SJ, Yen FC, Tsai SJ. Is dysfunction of the tissue plasminogen activator (tPA)-plasmin pathway a link between major depression and cardiovascular disease? Med Hypotheses. 2009; 72:166-8. https://doi.org/10.1016/j. mehy.2008.09.009.

84. Savoy C, Van Lieshout RJ, Steiner M. Is plasminogen activator inhibitor-1 a physiological bottleneck bridging major depressive disorder and cardiovascular disease? Acta Physiol (Oxf). 2017; 219:715-27. https://doi.org/10.1111/ apha. 12726.

85. Stafford L, Berk M. The use of statins after a cardiac intervention is associated with reduced risk of subsequent depression: proof of concept for the inflammatory and oxidative hypotheses of depression? J Clin Psychiatry. 2011; 72:1229-35. https://doi.org/10.4088/JCP.09m05825blu.

86. Williams LJ, Pasco JA, Mohebbi M, Jacka FN, Stuart AL, Venugopal K, O'Neil A, Berk M. Statin and Aspirin Use and the Risk of Mood Disorders among Men. Int $\mathrm{J}$ Neuropsychopharmacol. 2016. https://doi.org/10.1093/ijnp/ pyw008.

87. Lopez S, Peiretti F, Bonardo B, Juhan-Vague I, Nalbone G. Effect of atorvastatin and fluvastatin on the expression of plasminogen activator inhibitor type-1 in cultured human endothelial cells. Atherosclerosis. 2000; 152:359-66.

88. Mussoni L, Banfi C, Sironi L, Arpaia M, Tremoli E. Fluvastatin inhibits basal and stimulated plasminogen activator inhibitor 1 , but induces tissue type plasminogen activator in cultured human endothelial cells. Thromb Haemost. 2000; 84:59-64.
89. Tsai SJ. Statins may enhance the proteolytic cleavage of proBDNF: implications for the treatment of depression. Med Hypotheses. 2007; 68:1296-9. https://doi. org/10.1016/j.mehy.2006.09.043.

90. Zhang F, Luo J, Min S, Ren L, Qin P. Propofol alleviates electroconvulsive shock-induced memory impairment by modulating proBDNF/mBDNF ratio in depressive rats. Brain Res. 2016; 1642:43-50. https://doi.org/10.1016/j. brainres.2016.03.020.

91. Sundell IB, Ranby M. Oat husk fiber decreases plasminogen activator inhibitor type 1 activity. Haemostasis. 1993; 23:45-50.

92. Hoirisch-Clapauch S, Nardi AE. Improvement of Psychotic Symptoms and the Role of Tissue Plasminogen Activator. Int J Mol Sci. 2015; 16:27550-60. https://doi.org/10.3390/ ijms161126053.

93. Hoirisch-Clapauch S, Nardi AE. Markers of low activity of tissue plasminogen activator/plasmin are prevalent in schizophrenia patients. Schizophr Res. 2014; 159:118-23. https://doi.org/10.1016/j.schres.2014.08.011.

94. Forood A, Malekpour-Afshar R, Mahdavi A. Serum level of plasminogen activator inhibitor type- 1 in addicted patients with coronary artery disease. Addict Health. 2014; 6:119-26.

95. Oh J, Lee HJ, Song JH, Park SI, Kim H. Plasminogen activator inhibitor-1 as an early potential diagnostic marker for Alzheimer's disease. Exp Gerontol. 2014; 60:87-91. https://doi.org/10.1016/j.exger.2014.10.004.

96. Voetsch B, Loscalzo J. Genetic determinants of arterial thrombosis. Arterioscler Thromb Vasc Biol. 2004; 24:216-29. https://doi.org/10.1161/01.ATV.0000107402.79771.fc. 